\title{
A novel combination of bioelectrochemical system with peroxymonosulfate oxidation for enhanced azo dye degradation and $\mathrm{MnFe}_{2} \mathrm{O}_{4}$ catalyst regeneration
}

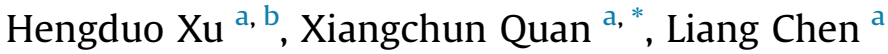 \\ ${ }^{a}$ Key Laboratory of Water and Sediment Sciences of Ministry of Education, State Key Laboratory of Water Environment Simulation, School of Environment, \\ Beijing Normal University, Beijing, 100875, PR China \\ ${ }^{\mathrm{b}}$ Key Laboratory of Coastal Biology and Utilization, Yantai Institute of Coastal Zone Research, Chinese Academy of Sciences, Yantai, Shandong, 264003, PR \\ China
}

\section{H I G H L I G H T S}

- $\mathrm{MnFe}_{2} \mathrm{O}_{4}$ catalyzed PMS oxidation driven by MFCs was established.

- Complete degradation of Orange II was achieved in the MFC- $\mathrm{MnFe}_{2} \mathrm{O}_{4}$ l PMS system.

- Electricity was recovered in the MFC$\mathrm{MnFe}_{2} \mathrm{O}_{4} / \mathrm{PMS}$ system during dye degradation.

- $\equiv \mathrm{Mn}^{2+}$ and $\equiv \mathrm{Fe}^{2+}$ was regenerated via cathode reduction of $\equiv \mathrm{Mn}^{3+}$ and $\equiv \mathrm{Fe}^{3+}$.

\section{A R T I C L E I N F O}

\section{Article history:}

Received 14 September 2018

Received in revised form

25 October 2018

Accepted 12 November 2018

Available online 13 November 2018

Handling Editor: Jun Huang

\section{Keywords}

$\mathrm{MnFe}_{2} \mathrm{O}_{4}$

Regeneration

Peroxymonosulfate

Azo dye

Microbial fuel cell
G R A P H I C A L A B S T R A C T

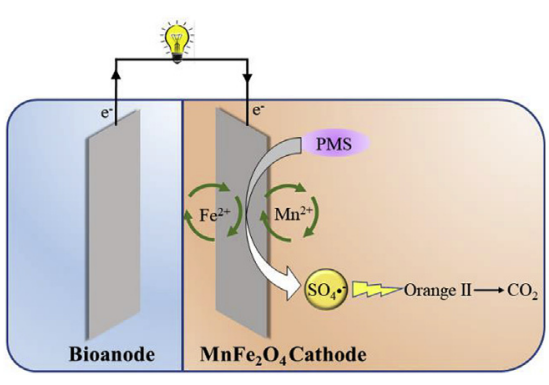

\section{A B S T R A C T}

Advanced oxidation process (AOP) based on peroxymonosulfate (PMS) activation was established in microbial fuel cell (MFC) system with $\mathrm{MnFe}_{2} \mathrm{O}_{4}$ cathode (MFC-MnFe $\mathrm{O}_{4} / \mathrm{PMS}$ ) aimed to enhance azo dye degradation and catalyst regeneration. The effects of loading amount of $\mathrm{MnFe}_{2} \mathrm{O}_{4}$ catalyst, applied voltage, catholyte $\mathrm{pH}$ and PMS dosage on the degradation of Orange II were investigated. The stability of the $\mathrm{MnFe}_{2} \mathrm{O}_{4}$ cathode for successive PMS activation was also evaluated. The degradation of Orange was accelerated in the MFC- $\mathrm{MnFe}_{2} \mathrm{O}_{4} / \mathrm{PMS}$ with apparent degradation rate constant increased to 1.8 times of that in the $\mathrm{MnFe}_{2} \mathrm{O}_{4} / \mathrm{PMS}$ control. A nearly complete removal of Orange II $\left(100 \mathrm{mg} \mathrm{L}^{-1}\right)$ was attained in the MFC- $\mathrm{MnFe}_{2} \mathrm{O}_{4} / \mathrm{PMS}$ under the optimum conditions of $2 \mathrm{mM} \mathrm{PMS}, 10 \mathrm{mg} \mathrm{cm}^{-2} \mathrm{MnFe}_{2} \mathrm{O}_{4}$ loading, $\mathrm{pH} 7$ -8 and 480 min reaction time. MFC driven also extended the longevity of the $\mathrm{MnFe}_{2} \mathrm{O}_{4}$ catalyst for PMS activation due to the in-situ regeneration of $\equiv \mathrm{Mn}^{2+}$ and $\equiv \mathrm{Fe}^{2+}$ through accepting electrons from the cathode, and over $80 \%$ of Orange II was still removed in the $7^{\text {th }}$ run. Additionally, the MFC-MnFe $2 \mathrm{O}_{4} / \mathrm{PMS}$ system could recover electricity during Orange II degradation with a maximum power density of $206.2 \pm 3.1 \mathrm{~mW} \mathrm{~m}^{-2}$. PMS activation by $\mathrm{MnFe}_{2} \mathrm{O}_{4}$ was the primary pathway for $\mathrm{SO}_{4}^{*-}$ generation, and $\mathrm{SO}_{4}^{-}$ based oxidation was the primary mechanism for Orange II degradation. MFCs driven coupled with PMS activated AOP systems provides a novel strategy for efficient and persistent azo dye degradation.

(C) 2018 Elsevier Ltd. All rights reserved.

\footnotetext{
* Corresponding author.

E-mail address: xchquan@bnu.edu.cn (X. Quan).
} 


\section{Introduction}

Azo dyes, which are aromatic compounds with one or more $-\mathrm{N}=\mathrm{N}-$ groups, are most commonly used synthetic dyes in textile industries. Most of azo dyes are resistant to microbial degradation and reported to be suspected carcinogenic and mutagenic compounds (Aguilar et al., 2017; Dai et al., 2018). Conventional biological wastewater treatment system generally cannot degrade azo dyes effectively due to their complex structure and strong toxicity (Pan et al., 2017; Zhang et al., 2015). The discharge of azo dye containing wastewater into water environment may reduce water transparency, retard light penetration for aquatic photosynthesis, and disturb ecosystem (Chen et al., 2018; Liang et al., 2018). It is therefore of great significance to find an effective approach to enhance azo dyes removal from wastewater.

Sulfate radical $\left(\mathrm{SO}_{4}^{-}\right)$based advanced oxidation processes (AOPs), as a promising technology for organic pollutants degradation, have drawn increasing attention recently (Hou et al., 2018). Comparing to traditional hydroxyl radical $\left(\mathrm{OH}^{*}\right), \mathrm{SO}_{4}^{-}$has the advantages of high standard reduction potential $(2.5-3.1 \mathrm{~V})$, good selectivity and independence of pH (Qi et al., 2016). A variety of transition metal catalysts can activate peroxymonosulfate (PMS, $\mathrm{HSO}_{5}^{-}$) to generate $\mathrm{SO}_{4}^{-}$, among which mixed metal or metal oxides, such as $\mathrm{MnFe}_{2} \mathrm{O}_{4}$ has received significant interests due to its polyfunctionality, better catalytic activity, and stability (Ghanbari and Moradi, 2017; Xiao et al., 2018a). When $\mathrm{MnFe}_{2} \mathrm{O}_{4}$ is used for PMS activation, $\mathrm{Mn}^{2+}$ can donate electron to $\mathrm{HSO}_{5}$ and promote it decompose to $\mathrm{SO}_{4}^{--}$, while the $\mathrm{Fe}^{3+}$ and generated $\mathrm{Mn}^{3+}$ need to be reduced to $\mathrm{Mn}^{2+}$ and $\mathrm{Fe}^{2+}$ to make the catalytic reaction of $\mathrm{MnFe}_{2} \mathrm{O}_{4}$ continuously. Catalysts recovery and regeneration is a bottleneck for practical application of the $\mathrm{MnFe}_{2} \mathrm{O}_{4}$ catalyst for PMS activation. Therefore, the regeneration rate of $\mathrm{Mn}^{2+}$ and $\mathrm{Fe}^{2+}$ is a key factor influencing $\mathrm{SO}_{4}^{--}$production and the longevity of the $\mathrm{MnFe}_{2} \mathrm{O}_{4}$ catalyst in the AOPs.

Bioelectrochemical system (BES) is novel technology for simultaneous organic pollutants degradation and electricity recovery. The electrochemically active bacteria colonized on the anodes can generate electrons through metabolizing organic compounds and deliver them to the cathodes, where some metals at high valence may be reduced after accepting electrons. For example, $\mathrm{Fe}^{3+}, \mathrm{Cr}^{6+}$, $\mathrm{Cu}^{2+}$ and $\mathrm{V}^{5+}$ could be reduced at the cathode of Microbial Fuel Cells (MFCs) (Lefebvre et al., 2012; Zhang et al., 2012; Huang et al., 2015). Depending on the redox cycles of $\mathrm{Fe}^{2+} / \mathrm{Fe}^{3+}$ and $\mathrm{H}_{2} \mathrm{O}_{2}$ generation at the cathode of MFCs, Fenton based AOPs was constructed previously (Feng et al., 2010). Additionally, MFCs as an external power supply have been reported to drive PMS activation directly but with a lower efficiency comparing to metal catalysts (Yan et al., 2017). Therefore, we hypothesize here that MFCs assistance may have a positive function in promoting metal catalyst regeneration and PMS activation. Combination of MFCs with AOPs based on PMS activation has never been investigated and deserves further study.

In this research, a MFC coupled $\mathrm{MnFe}_{2} \mathrm{O}_{4} / \mathrm{PMS}$ system (named as MFC-MnFe ${ }_{2} \mathrm{O}_{4} / \mathrm{PMS}$ ) was established in the cathode chamber of a MFC using a $\mathrm{MnFe}_{2} \mathrm{O}_{4}$ modified cathode with PMS containing catholyte. The degradation of azo dye Orange II and power generation capacity in the MFC- $\mathrm{MnFe}_{2} \mathrm{O}_{4} / \mathrm{PMS}$ system were investigated. The effects of loading amount of $\mathrm{MnFe}_{2} \mathrm{O}_{4}$, applied voltage, catholyte $\mathrm{pH}$ and PMS dosage on the degradation of Orange II were examined. The stability of the $\mathrm{MnFe}_{2} \mathrm{O}_{4}$ cathode for successive PMS activation was also evaluated, and a possible reaction mechanism for PMS activation and Orange II degradation in the system was proposed.

\section{Materials and methods}

\subsection{Chemicals and materials}

A non-wet proofed carbon cloth and carbon paper (HeSen Co. Ltd, Shanghai, China) were used as the supporting material of the anode and cathode electrodes, respectively. These carbon-based electrodes were pretreated using acetone and under high temperature prior to use. $\mathrm{Fe}\left(\mathrm{NO}_{3}\right)_{3} \cdot 9 \mathrm{H}_{2} \mathrm{O}$ and $\mathrm{Mn}\left(\mathrm{NO}_{3}\right)_{2} \cdot 4 \mathrm{H}_{2} \mathrm{O}$ were purchased from Aladdin Chemical Reagent Co. (Shanghai, China). Orange II and PMS (Oxone, $\mathrm{KHSO}_{5} \cdot 0.5 \mathrm{KHSO}_{4} \cdot 0.5 \mathrm{~K}_{2} \mathrm{SO}_{4}, 4.7 \%$ active oxygen) were purchased from Sigma-Aldrich (purity $>99 \%$ ). Unless otherwise specified, all the reagents used in this study were of analytical grade.

\subsection{Synthesis of $\mathrm{MnFe}_{2} \mathrm{O}_{4}$ particles}

The $\mathrm{MnFe}_{2} \mathrm{O}_{4}$ particles were synthesized using a modified coprecipitation method according to the procedure previously described by Yao et al. (2014a). Briefly, $0.29 \mathrm{~g} \mathrm{Fe}\left(\mathrm{NO}_{3}\right)_{3} \cdot 9 \mathrm{H}_{2} \mathrm{O}$ and $0.20 \mathrm{~g} \mathrm{Mn}\left(\mathrm{NO}_{3}\right)_{2} \cdot 4 \mathrm{H}_{2} \mathrm{O}$ were dissolved in $80 \mathrm{~mL}$ of pure water with a final molar ratio of $\mathrm{Fe}^{3+} / \mathrm{Mn}^{2+}$ of $2: 1$, which was equal to the theoretic molar ratio of manganese and ferrite in $\mathrm{MnFe}_{2} \mathrm{O}_{4}$. The resulting mixed solution was then added by $0.64 \mathrm{~g}$ of $\mathrm{NaOH}$ and stirred for $10 \mathrm{~min}$ for complete dissolution. Then aqueous hydrazine solution ( $35 \mathrm{wt} \%$ ) as reducing agent was added into the dispersion and stirred for another $10 \mathrm{~min}$. The resulting mixture was then transferred into a $100 \mathrm{~mL}$ Teflon-lined stainless-steel autoclave and heated at $180^{\circ} \mathrm{C}$ for $24 \mathrm{~h}$ in an oven. After cooling to room temperature, the precipitate of $\mathrm{MnFe}_{2} \mathrm{O}_{4}$ particles was filtered out and washed with deionized water until the $\mathrm{pH}$ of the suspension reached 7 , and then dried at $60^{\circ} \mathrm{C}$ overnight in a vacuum oven for further use.

\subsection{Preparation of $\mathrm{MnFe}_{2} \mathrm{O}_{4}$ modified electrode}

$\mathrm{MnFe}_{2} \mathrm{O}_{4}$ modified electrode was prepared according to the following procedure using carbon paper as the supporting material. Firstly, the synthesized $\mathrm{MnFe}_{2} \mathrm{O}_{4}$ particles was mixed with carbon black, and then added by Nafion solution (5\%) to make a paste. The carbon paper was evenly spread by the mixture paste using a spray gun coupled with vacuum pump, and then dried at $25^{\circ} \mathrm{C}$ overnight. The loading amount of $\mathrm{MnFe}_{2} \mathrm{O}_{4}$ particles on the electrodes varied from 2 to $20 \mathrm{mg} \mathrm{cm}^{-2}$. An electrode modified with carbon black alone without $\mathrm{MnFe}_{2} \mathrm{O}_{4}$ particles was also prepared as a control. At least three repeatable samples were prepared for each type of the above electrodes and used for the following experiments.

\subsection{MFC setup and operation}

Dual-chamber MFCs were constructed as previously described, which had a working volume of $96 \mathrm{~mL}(6 \mathrm{~cm} \times 4 \mathrm{~cm} \times 4 \mathrm{~cm}$, length $\times$ width $\times$ height) for each chamber and between which separated by a proton exchange membrane (PEM) (Nafion 117, DuPont Co., USA) (Xu et al., 2018). During the start-up period, a piece of carbon cloth $\left(4 \times 2 \mathrm{~cm}^{2}\right)$ was used as the anode electrode, and a carbon paper $\left(4 \times 2 \mathrm{~cm}^{2}\right)$ with $\mathrm{Pt}\left(0.5 \mathrm{mg} \mathrm{cm}^{-2}\right)$ catalysts was used as the cathode electrode. The anodic chamber was inoculated with anaerobic sludge collected from Yanjing wastewater treatment plant (Beijing, China) to enrich electroactive bacteria. The anolyte consisted of $\mathrm{CH}_{3} \mathrm{COONa} 1.64 \mathrm{~g} \mathrm{~L}^{-1}, \mathrm{NH}_{4} \mathrm{Cl} 0.31 \mathrm{~g} \mathrm{~L}^{-1}, \mathrm{KCl}$ $0.13 \mathrm{~g} \mathrm{~L}^{-1}, \mathrm{Na}_{2} \mathrm{HPO}_{4} \cdot 12 \mathrm{H}_{2} \mathrm{O} 10.32 \mathrm{~g} \mathrm{~L}^{-1}, \mathrm{NaH}_{2} \mathrm{PO}_{4} \cdot 2 \mathrm{H}_{2} \mathrm{O} 3.32 \mathrm{~g} \mathrm{~L}^{-1}$, a vitamin solution $5 \mathrm{~mL}$ and trace mineral solution $12.5 \mathrm{~mL}$ (Wu et al., 
2016). The catholyte was $50 \mathrm{mM}$ phosphate buffer solution $(\mathrm{pH}=7)$. When the MFCs achieved stable electricity production after three-month operation, the original cathode electrode was replaced by the $\mathrm{MnFe}_{2} \mathrm{O}_{4}$ electrodes or CB control electrode, PMS at various concentrations $(0.5-4 \mathrm{mM})$ was also added to the cathode chamber. In this way, a MFC- $\mathrm{MnFe}_{2} \mathrm{O}_{4} / \mathrm{PMS}$ based AOPs was established. Orange II $\left(100 \mathrm{mg} \mathrm{L}^{-1}\right)$ was selected as the target azo dye and added to the cathode chamber. The anode was connected to a cathode across a $50 \Omega$ external resistor by titanium wires. All the MFCs were operated at $30 \pm 1{ }^{\circ} \mathrm{C}$. Water samples were withdrawn from the cathode chamber at certain intervals and the remaining concentration of the azo dye was determined.

\subsection{Measurements and characterization}

Voltage $(V)$ across the resistor was measured using a data acquisition system (USB8253, RBH Co., China) every 10 min. Polarization curves were measured by varying external resistances from 10000 to $100 \Omega$. Power density and current density were normalized by the project surface area of the anode. The electrochemical catalytic properties of the $\mathrm{MnFe}_{2} \mathrm{O}_{4}$ modified electrode were investigated by scanning CV curves using a CHI660 electrochemical workstation (Chenhua, China) at a scan rate of $25 \mathrm{mV} \mathrm{s}^{-1}$, with the $\mathrm{MnFe}_{2} \mathrm{O}_{4}$ modified electrode as the working electrode, a Pt thin film electrode as the counter electrode, and an $\mathrm{Ag} / \mathrm{AgCl}$ electrode as the reference electrode. The metal oxidation states of the $\mathrm{MnFe}_{2} \mathrm{O}_{4}$ onto the cathodes before and after application in the MFC-MnFe ${ }_{2} \mathrm{O}_{4} /$ PMS system were characterized by X-ray photoelectron spectroscopy (XPS) under $\mathrm{Cu} \mathrm{K} \alpha$ radiation (Escalab 250Xi, USA). The surface morphology of the $\mathrm{MnFe}_{2} \mathrm{O}_{4}$ was characterized by a field emission scanning electron microscopy (SEM, Hitachi S4800, Japan). An energy dispersive spectrometer (EDS, EDAX9100, USA) coupled to the SEM was used to analyze the metal elements of $\mathrm{MnFe}_{2} \mathrm{O}_{4}$. X-ray diffraction (XRD, $\mathrm{X}^{\prime}$ Pert PRO MPD, Nederland) patterns were performed at a step of $8^{\circ} \mathrm{min}^{-1}$ from $10^{\circ}$ to $80^{\circ}$ using a Trax theta-theta diffractometer with $\mathrm{Cu} \mathrm{K} \alpha$ radiation $(40 \mathrm{kV}$ and $40 \mathrm{~mA}$ ).

The concentration of Orange II was determined using a UV-Visible spectrophotometer (DR 6000, HACH, USA) at the maximum visible absorption wavelength of $486 \mathrm{~nm}$. Total organic carbon (TOC) was measured using a TOC-V analyzer (Shimadzu Co., Japan). All the above experiments were conducted in triplicates.

\section{Results and discussion}

\subsection{Characterization of the $\mathrm{MnFe}_{2} \mathrm{O}_{4}$ modified electrode}

$\mathrm{MnFe}_{2} \mathrm{O}_{4}$ modified electrodes were prepared and their surface morphology were characterized by SEM (Fig. $1 \mathrm{~A}, \mathrm{~B}$ ). It is obvious to see that the $\mathrm{MnFe}_{2} \mathrm{O}_{4}$ particles were evenly dispersed on the surface of carbon paper electrodes. Carbon black as the support and dispersant not only prevented the $\mathrm{MnFe}_{2} \mathrm{O}_{4}$ particles from agglomeration, but also helped the catalyst particles tightly anchored to the electrode. Carbon black can also help to promote electron transfer between the $\mathrm{MnFe}_{2} \mathrm{O}_{4}$ and electrode (Higuchi et al., 2005). The EDS image (Fig. 1C) confirms the presence of the elements of $\mathrm{Mn}$, Fe and $\mathrm{O}$ in the catalyst. The atomic ratio (\%) of Fe to $\mathrm{Mn}$ was 1.8 , which is close to the theoretical value of the designed $\mathrm{MnFe}_{2} \mathrm{O}_{4}$ (2.0) (Table S1). The XRD pattern of $\mathrm{MnFe}_{2} \mathrm{O}_{4}$ is shown in Fig. 1D. $\mathrm{MnFe}_{2} \mathrm{O}_{4}$ exhibits a typical pattern of spinel ferrite with well-defined peaks occurring at $2 \theta=18.15^{\circ}, 30.01^{\circ}, 35.06^{\circ}$, $43.62^{\circ}, 54.18^{\circ}, 56.45^{\circ}$ and $61.86^{\circ}$. These peaks are indexed to (111), (220), (311), (400), (422), (511) and (440) Bragg planes of the $\mathrm{MnFe}_{2} \mathrm{O}_{4}$ cubic type (JCPDS card No. 73-1964). No other peaks are observed, implying that the synthesized $\mathrm{MnFe}_{2} \mathrm{O}_{4}$ was composed of single phase.

The electrochemical properties of the $\mathrm{MnFe}_{2} \mathrm{O}_{4}$ modified electrode were investigated through measuring $\mathrm{CVs}$ in a $10 \mathrm{mM}$ $\mathrm{K}_{3} \mathrm{Fe}(\mathrm{CN})_{6} / \mathrm{K}_{4} \mathrm{Fe}(\mathrm{CN})_{6}$ electrolyte (Fig. 2). Both the $\mathrm{MnFe}_{2} \mathrm{O}_{4}$ modified electrode and control electrode demonstrated the property of electrocatalytic oxidation and reduction of $\left[\mathrm{Fe}(\mathrm{CN})_{6}\right]^{4+} /\left[\mathrm{Fe}(\mathrm{CN})_{6}\right]^{3+}$. The $\mathrm{MnFe}_{2} \mathrm{O}_{4}$ electrode showed a higher peak current density (anodic peak: $3.24 \mathrm{~mA} \mathrm{~cm}^{-2}$, cathodic peak: $2.35 \mathrm{~mA} \mathrm{~cm}^{-2}$ ) than the control electrode (anodic peak: $2.75 \mathrm{~mA} \mathrm{~cm}^{-2}$, cathodic peak: $1.47 \mathrm{~mA} \mathrm{~cm}^{-2}$ ). The electrochemical active surface area was calculated based on the Randles-Sevcik equation (detailed equation shown in Supporting Information), and the $\mathrm{MnFe}_{2} \mathrm{O}_{4}$ electrode showed a larger active surface area $\left(195.59 \mathrm{~cm}^{2}\right)$ than the control electrode $\left(122.49 \mathrm{~cm}^{2}\right)$, which is more beneficial for the occurrence of electrochemical reaction and physical adsorption (Allen and Larry, 2001). Moreover, a larger absolute area of the CV curve was found for the $\mathrm{MnFe}_{2} \mathrm{O}_{4}$ electrode comparing to the control, suggesting a relatively higher specific capacitance of the $\mathrm{MnFe}_{2} \mathrm{O}_{4}$ electrode (Peng et al., 2012). One more pair of peaks were observed for the $\mathrm{MnFe}_{2} \mathrm{O}_{4}$ modified electrode at the potential of $0.43 \mathrm{~V}$ and $0.76 \mathrm{~V}$, which might be attributed to the redox couple of $\mathrm{Mn}^{3+}$ / $\mathrm{Mn}^{2+}$

\subsection{Orange II degradation in the $\mathrm{MFC}-\mathrm{MnFe}_{2} \mathrm{O}_{4} / \mathrm{PMS}$ system}

A MFC coupled $\mathrm{MnFe}_{2} \mathrm{O}_{4} / \mathrm{PMS}$ system was established through loading $10 \mathrm{mg} \mathrm{cm}^{-2} \mathrm{MnFe}_{2} \mathrm{O}_{4}$ to the cathode electrode and adding $2 \mathrm{mM}$ PMS in the catholyte $(\mathrm{pH}=7)$. For comparative purposes, a $\mathrm{MnFe}_{2} \mathrm{O}_{4} / \mathrm{PMS}$ system without MFC driven was also investigated as a control. The degradation of Orange II in the MFC- $\mathrm{MnFe}_{2} \mathrm{O}_{4} / \mathrm{PMS}$ system was evaluated (Fig. $3 \mathrm{~A}$ ) and the results were fitted to pseudo-first order kinetics according to the following equation :

$\ln \left(\frac{C}{C_{0}}\right)=-k_{\text {app }} t$

where $C$ and $C_{0}$ are the real-time concentration and the initial concentration, respectively, $k_{a p p}$ is the apparent rate constant, and $t$ is the reaction time.

It is obvious to see that the degradation of Orange II was enhanced in the MFC- $\mathrm{MnFe}_{2} \mathrm{O}_{4} / \mathrm{PMS}$ system compared to $\mathrm{MnFe}_{2} \mathrm{O}_{4} /$ PMS alone system, with a removal percentage of $98.5 \pm 1.0 \%$ and $91.2 \pm 1.2 \%$ obtained within $480 \mathrm{~min}$, respectively. The apparent degradation rate constant of Orange II was $0.0092 \mathrm{~min}^{-1}$ in the MFC- $\mathrm{MnFe}_{2} \mathrm{O}_{4} / \mathrm{PMS}$ system, which was 1.8 times of the value (0.0051 $\mathrm{min}^{-1}$ ) achieved in the $\mathrm{MnFe}_{2} \mathrm{O}_{4} / \mathrm{PMS}$ control system (Fig. 3B). For the MFC system with a $\mathrm{MnFe}_{2} \mathrm{O}_{4}$ cathode but no PMS in the catholyte, only $22.1 \pm 2.9 \%$ of Orange II was degraded. When the $\mathrm{CB}$ cathode was used as the control in the MFC system, only $15.0 \pm 3.7 \%$ of Orange II was degraded no matter PMS existed or not. These results suggest that MFC loaded with the CB cathode could not activate PMS and degrade Orange II effectively under the tested conditions. Although Orange II could also be reduced at the cathode after accepting the electrons, it is not the primary way for Orange II reduction. The $\mathrm{MnFe}_{2} \mathrm{O}_{4}$ modified cathode in the MFCs played a primary role in PMS activation, which may contribute greatly to Orange II degradation in the MFC- $\mathrm{MnFe}_{2} \mathrm{O}_{4} / \mathrm{PMS}$ system.

To know the mineralization degree of Orange II, the effluent TOC was also measured during Orange II degradation, and the results were presented in Fig. S1. TOC was removed by $94.1 \pm 4.1 \%$ and $81.1 \pm 7.9 \%$ in the MFC-MnFe $\mathrm{O}_{4} / \mathrm{PMS}$ system and $\mathrm{MnFe}_{2} \mathrm{O}_{4} / \mathrm{PMS}$ alone system, respectively, which were comparable to the degradation level of Orange II. This result indicated that most of the azo dye removed in the system was mineralized based on advanced oxidation process. 

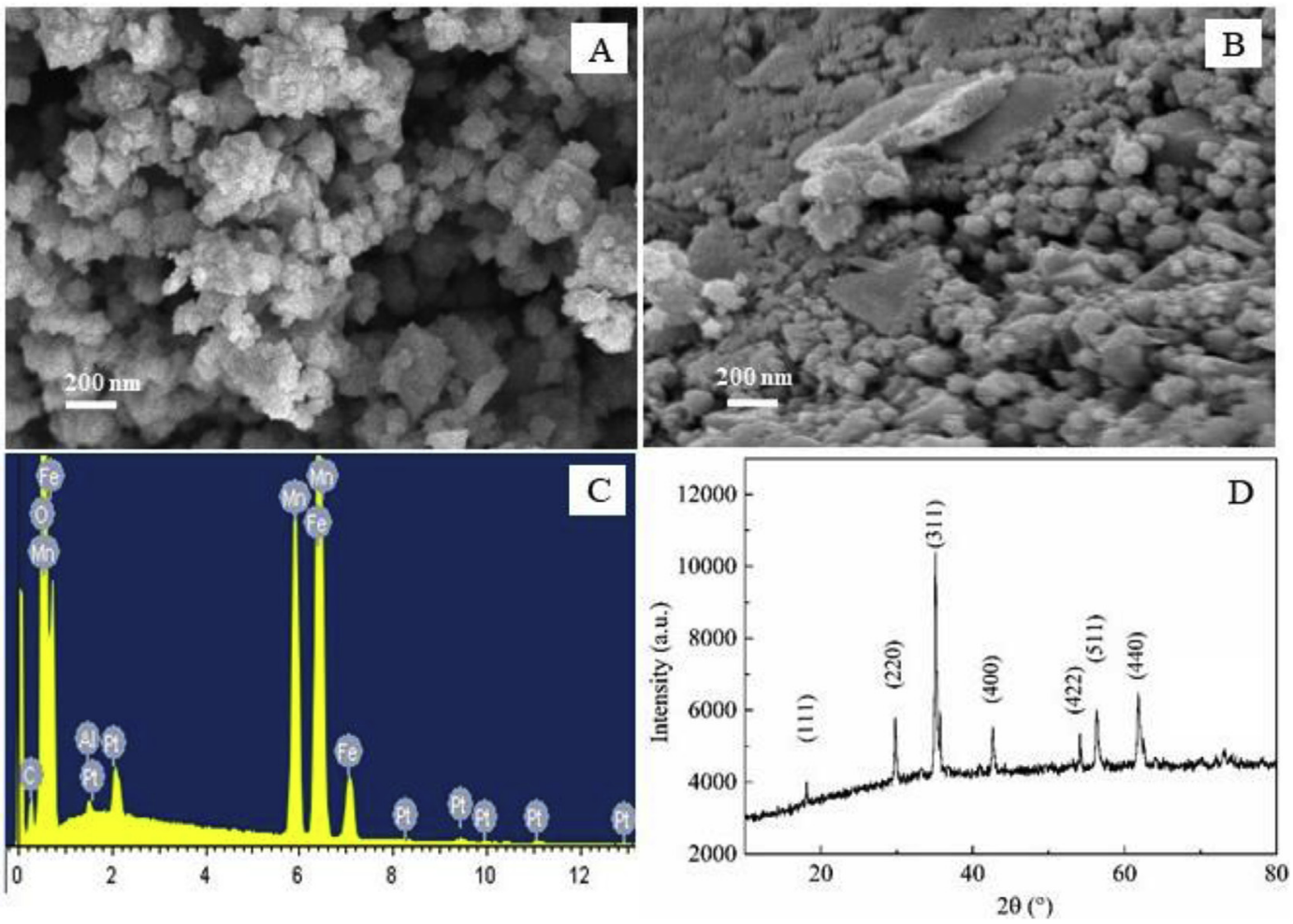

Fig. 1. SEM images (A, B) showing the surface morphology of the $\mathrm{MnFe}_{2} \mathrm{O}_{4}$ modified electrodes and their corresponding EDS (C) and XRD (D) patterns.

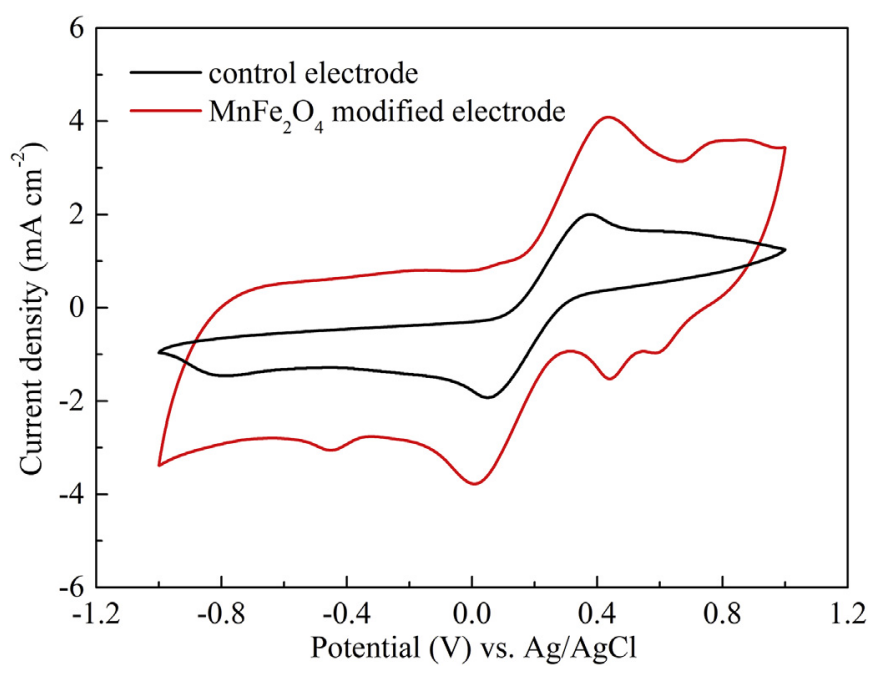

Fig. 2. Cyclic voltammograms for the $\mathrm{MnFe}_{2} \mathrm{O}_{4}$ electrode and the control electrode in $10 \mathrm{mM} \mathrm{K}_{3} \mathrm{Fe}(\mathrm{CN})_{6} / \mathrm{K}_{4} \mathrm{Fe}(\mathrm{CN})_{6}$ with $0.1 \mathrm{M} \mathrm{KCl}$ as the supporting electrolyte at a scanning rate of $25 \mathrm{mV} \mathrm{s}^{-1}$ between $-1 \mathrm{~V}$ and $1 \mathrm{~V}$.

\subsection{Factors influencing orange II degradation in the $\mathrm{MFC}-\mathrm{MnFe}_{2} \mathrm{O}_{4} /$ PMS system}

Effects of various factors including PMS dosage, $\mathrm{MnFe}_{2} \mathrm{O}_{4}$ loading amount on the electrode, catholyte medium $\mathrm{pH}$, and applied voltage on the performance of the MFC- $\mathrm{MnFe}_{2} \mathrm{O}_{4} / \mathrm{PMS}$ system were further examined and the results were presented in Fig. 4. It was obvious to see that the Orange II degradation rate increased with increasing PMS dosage within the range of $0.5-4 \mathrm{mM}$ (Fig. 4A), possibly because of the high $\mathrm{SO}_{4}^{--}$generation rate at high PMS doses. PMS dosage also determined the final removal level of Orange II. When PMS dosage increased from $0.5 \mathrm{mM}$ to $2 \mathrm{mM}$, the removal percentage of Orange II increased from $57.6 \pm 2.8 \%$ to $98.5 \pm 1.0 \%$, and it remained this level when the PMS dosage further increased to $4 \mathrm{mM}$ possibly because of $\mathrm{SO}_{4}^{--}$ scavenge effect at high PMS dosage (Jaafarzadeh et al., 2017; Shao et al., 2017). Similar result was also reported by Zhou et al. (2018). They found that the degradation of 2,4-dichlorophenol in $\mathrm{FeCO}_{2} \mathrm{O}_{4} / \mathrm{PMS}$ system was not strictly dependent on PMS dosage. The PMS dosage may influence degradation rate and removal level of azo dye via influencing the $\mathrm{SO}_{4}^{--}$generation amount and rate.

Fig. 4B showed the effect of $\mathrm{MnFe}_{2} \mathrm{O}_{4}$ loading amount on the electrode on Orange II degradation in the MFC-MnFe $\mathrm{O}_{4} / \mathrm{PMS}$ system. The apparent degradation rate constant kept increasing from $0.0026 \mathrm{~min}^{-1}$ to $0.0092 \mathrm{~min}^{-1}$ when the $\mathrm{MnFe}_{2} \mathrm{O}_{4}$ loading increased from 2 to $10 \mathrm{mg} \mathrm{cm}^{-2}$, but slightly declined to 0.0086 $\mathrm{min}^{-1}$ when the loading further increased to $20 \mathrm{mg} \mathrm{cm}^{-2}$. A removal percentage of $73.2 \%$ was obtained using the cathode of $2 \mathrm{mg} \mathrm{cm}^{-2} \mathrm{MnFe}_{2} \mathrm{O}_{4}$ within $480 \mathrm{~min}$, while a complete removal was achieved using the cathode of $10 \mathrm{mg} \mathrm{cm}^{-2} \mathrm{MnFe}_{2} \mathrm{O}_{4}$ within 240 min. The electrode with more $\mathrm{MnFe}_{2} \mathrm{O}_{4}$ catalyst may create more effective active sites for the formation of $\mathrm{SO}_{4}^{--}$and therefore accelerated Orange II degradation. However, when the catalyst loading amount increased beyond a critical value, excessive catalyst dosage may cause ineffective PMS consumption, which may be the reason for the declined degradation rate at the high loading of $20 \mathrm{mg} \mathrm{cm}^{-2} \mathrm{MnFe}_{2} \mathrm{O}_{4}$ (Guan et al., 2013). Similar phenomena was reported by Xia et al. (2017), in which the amount of magnetic pyrrhotite $\left(\mathrm{FeS}_{2}\right)$ catalyst influenced $\mathrm{SO}_{4}^{--}$generation rate in the $\mathrm{FeS}_{2} /$ PMS system, but it was not strictly proportional to the inactivation efficiency of Escherichia. Coli.

As the performance of AOPs is $\mathrm{pH}$ dependent mostly, the effect of catholyte $\mathrm{pH}$ on the degradation of Orange II in the MFC$\mathrm{MnFe}_{2} \mathrm{O}_{4} / \mathrm{PMS}$ system was explored (Fig. 4C) (Ren et al., 2015; Zhao et al., 2017). The apparent degradation rate constant attained a 

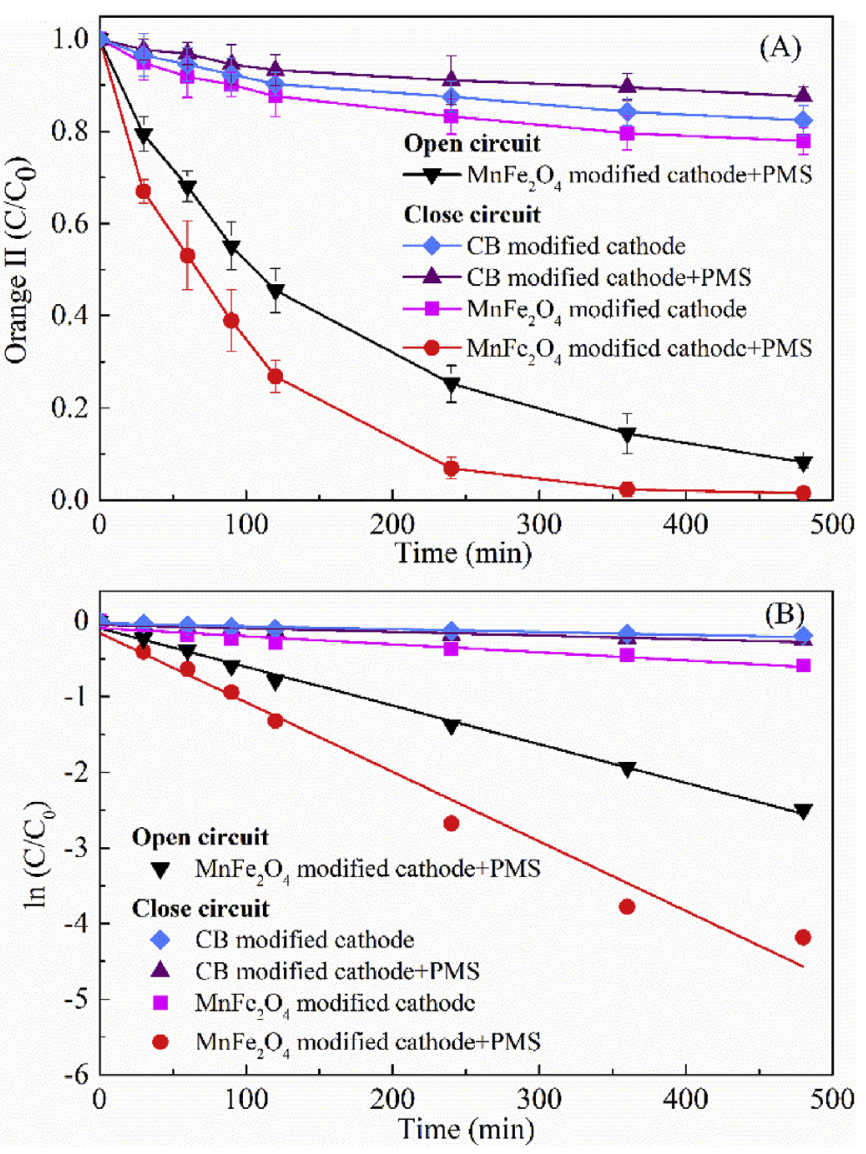

Fig. 3. Orange II degradation versus reaction time in MFC-PMS system and MFC alone, respectively, under different operation modes (A) and kinetic analysis of Orange II degradation (B). Error bars represent standard deviations from triplicate tests. (For interpretation of the references to colour in this figure legend, the reader is referred to the Web version of this article.)

maximum value of $0.0094 \mathrm{~min}^{-1}$ at $\mathrm{pH}=8$, while it declined to $0.0068 \mathrm{~min}^{-1}$ and $0.0057 \mathrm{~min}^{-1}$ at $\mathrm{pH}=5$ and $\mathrm{pH}=10$, respectively. The relatively low Orange II degradation rate at acidic $\mathrm{pH}$ was possibly because of the formation of $\left(\mathrm{Mn}^{2+}\left(\mathrm{H}_{2} \mathrm{O}\right)\right)^{2+}$ which may reduce free $\mathrm{Mn}^{2+}$ available on the cathode (Wang and Chu, 2011). In addition, PMS mainly exists as $\mathrm{HSO}_{5}^{-}$at the $\mathrm{pH}$ of $6-8$ according to the second $\mathrm{p} K_{a}$ value of PMS (second $\mathrm{p} K_{a}$ is 9.4) (Zhao et al., 2018). The stabilization effect of $\mathrm{H}^{+}$on the $\mathrm{HSO}_{5}^{-}$at acidic $\mathrm{pH}$ may also retard the degradation of Orange II (Rani et al., 2009). The degradation of Orange II was also inhibited slightly at $\mathrm{pH}=10$, possibly because $\mathrm{MnFe}_{2} \mathrm{O}_{4}$ is negatively charged under alkaline conditions, which was unbeneficial for the absorption of $\mathrm{HSO}_{5}^{-}$and $\mathrm{SO}_{5}^{2-}$ (Huang et al., 2017). Therefore, the optimum pH value for Orange II degradation in the MFC-MnFe $\mathrm{O}_{4} / \mathrm{PMS}$ system was 7-8.

All the above results indicated MFC driven enhanced Orange II degradation in the $\mathrm{MnFe}_{2} \mathrm{O}_{4} / \mathrm{PMS}$ system. When an external voltage was applied to the $\mathrm{MnFe}_{2} \mathrm{O}_{4} / \mathrm{PMS}$ system to improve electron transfer to the cathode, its effect on the degradation of Orange II was further investigated (Fig. 4D). Results showed that an applied voltage of $0.4 \mathrm{~V}$ and $0.8 \mathrm{~V}$ accelerated Orange II degradation with apparent rate constant increased to $0.0096 \mathrm{~min}^{-1}$ and 0.0101 $\mathrm{min}^{-1}$, respectively, compared to that without an applying voltage $\left(0.0092 \mathrm{~min}^{-1}\right)$. More electrons may be delivered to the cathode electrode and used for $\mathrm{Mn}^{2+}$ or $\mathrm{Fe}^{2+}$ regeneration and PMS activation, which may be the reason for the accelerated degradation rate.

\subsection{Catalyst stability after long-term application}

The reusability of catalyst is a crucial factor that determines its long-term application in practice. Successive batch experiments were conducted to evaluate the catalytic stability of $\mathrm{MnFe}_{2} \mathrm{O}_{4}$ in the MFC- $\mathrm{MnFe}_{2} \mathrm{O}_{4} / \mathrm{PMS}$ system under open-circuit and close-circuit conditions (Fig. 5). Results showed that the MFC-MnFe $\mathrm{O}_{4} / \mathrm{PMS}$ system maintained a good degradation towards Orange II with $98.9 \%$ removal in the 1 st run and $83.9 \%$ removal in the 7 th run (480 min). However, for the $\mathrm{MnFe}_{2} \mathrm{O}_{4} /$ PMS control system (opening-circuit), the removal percentage of Orange II declined quickly from $92.6 \%$ in the $1^{\text {st }}$ run to $49.3 \%$ in the $7^{\text {th }}$ run. These data indicated that the MFC- $\mathrm{MnFe}_{2} \mathrm{O}_{4} /$ PMS system not only accelerated Orange II degradation but also prolonged the longevity and reusability of $\mathrm{MnFe}_{2} \mathrm{O}_{4}$ catalyst, which may be due to the in-situ regeneration of $\equiv \mathrm{Mn}^{2+}$ and $\equiv \mathrm{Fe}^{2+}$ on cathode after accepting electrons from the anode of MFC. For the $\mathrm{MnFe}_{2} \mathrm{O}_{4} / \mathrm{PMS}$ control system, the $\mathrm{MnFe}_{2} \mathrm{O}_{4}$ catalyst decayed faster possibly due to the consumption of $\equiv \mathrm{Mn}^{3+}$ and generation of $\mathrm{SO}_{5}^{--}(1.1 \mathrm{~V})$, which is a relatively weaker transient radical species and cannot be used for Orange II degradation (Cai et al., 2015; Li et al., 2018).

\subsection{Power generation in the MFC-MnFe $\mathrm{O}_{4} / \mathrm{PMS}$ system}

When the MFC- $\mathrm{MnFe}_{2} \mathrm{O}_{4} / \mathrm{PMS}$ system was used for azo dye degradation, electricity could also be recovered. The power density curves and polarization curves during Orange II degradation were measured in the MFC with the $\mathrm{MnFe}_{2} \mathrm{O}_{4}$ cathode or the control CB cathode (Fig. 6). As illustrated in Fig. 6A, the MFC with the $\mathrm{MnFe}_{2} \mathrm{O}_{4}$ cathode generated a maximum power density of $206.2 \pm 3.1 \mathrm{~mW} \mathrm{~m}^{-2}$ at a current density of $574.4 \mathrm{~mA} \mathrm{~m}^{-2}$, which was 13-folds greater than that obtained with the CB control cathode $\left(15.5 \pm 0.4 \mathrm{~mW} \mathrm{~m}^{-2}\right.$ at a current density of $\left.111.2 \mathrm{~mA} \mathrm{~m}^{-2}\right)$. When the PMS dosage varied in the catholyte, power generation also changed, with a maximum power density of $167.1 \pm 2.8$, $177.6 \pm 5.2,206.2 \pm 3.1$ and $209.7 \pm 2.9 \mathrm{~mW} \mathrm{~m}^{-2}$ generated in the MFC- $\mathrm{MnFe}_{2} \mathrm{O}_{4} / \mathrm{PMS}$ system at the PMS dosage of $0.5,1,2$ and $4 \mathrm{mM}$, respectively (Fig. 6B). As the redox potential of $\mathrm{HSO}_{5}^{-} / \mathrm{SO}_{4}^{--}(1.82 \mathrm{~V}$, vs. normal hydrogen electrode, NHE) is significantly higher than that of $\mathrm{Mn}^{3+} / \mathrm{Mn}^{2+}(1.54 \mathrm{~V}), \mathrm{Fe}^{3+} / \mathrm{Fe}^{2+}(0.77 \mathrm{~V})$ and $\mathrm{O}_{2} / \mathrm{H}_{2} \mathrm{O}(0.81 \mathrm{~V})$, PMS may preferentially accept electrons (Chen et al., 2007). PMS as the dominant electron accepter in the MFC-MnFe ${ }_{2} \mathrm{O}_{4} / \mathrm{PMS}$ system determined the cathode potential and further affected the power generation (Sangeun et al., 2004). Increasing the PMS dosage in the catholyte may generate more $\mathrm{SO}_{4}^{-}$as electron acceptor in the MFC$\mathrm{MnFe}_{2} \mathrm{O}_{4} / \mathrm{PMS}$ system, which may be the reason for the increased power density at a relatively high PMS dosage (2-4 mM).

\subsection{Mechanism for pollutant degradation in the $\mathrm{MFC}-\mathrm{MnFe}_{2} \mathrm{O}_{4} /$ PMS system}

The XPS spectra were used to investigate the changes of chemical status of $\mathrm{Mn}$ and $\mathrm{Fe}$ on the $\mathrm{MnFe}_{2} \mathrm{O}_{4}$ cathode before and after application in the MFC- $\mathrm{MnFe}_{2} \mathrm{O}_{4} / \mathrm{PMS}$ system. Fig. S2 showed the XPS spectra of Mn $2 p$ and Fe $2 p$ core level regions. For the original $\mathrm{MnFe}_{2} \mathrm{O}_{4}$ samples, the peaks at the binding energy of $641.8 \mathrm{eV}$ and $653.3 \mathrm{eV}$ are assigned to $\mathrm{Mn} 2 \mathrm{p}_{3 / 2}$ and $2 \mathrm{p}_{1 / 2}$, respectively, indicating that $\mathrm{Mn}$ element existed in the chemical state of $\mathrm{Mn}^{2+}$ in the $\mathrm{MnFe}_{2} \mathrm{O}_{4}$ catalyst (Fig. S2A). Meanwhile, the peak with binding energy appeared at $711.5 \mathrm{eV}$ and a satellite signal at $719.3 \mathrm{eV}$ were also observed, indicating the presence of $\mathrm{Fe}^{3+}$ in the $\mathrm{MnFe}_{2} \mathrm{O}_{4}$ catalyst (Fig. S2B) (Yao et al., 2014b). The peak areas representing $\mathrm{Mn}^{2+}$ and $\mathrm{Fe}^{3+}$ declined apparently for the used $\mathrm{MnFe}_{2} \mathrm{O}_{4}$ cathode, indicating the change of valence state of $\mathrm{Mn}^{2+}$ and $\mathrm{Fe}^{3+}$ after reaction with PMS. Similar results were also reported 

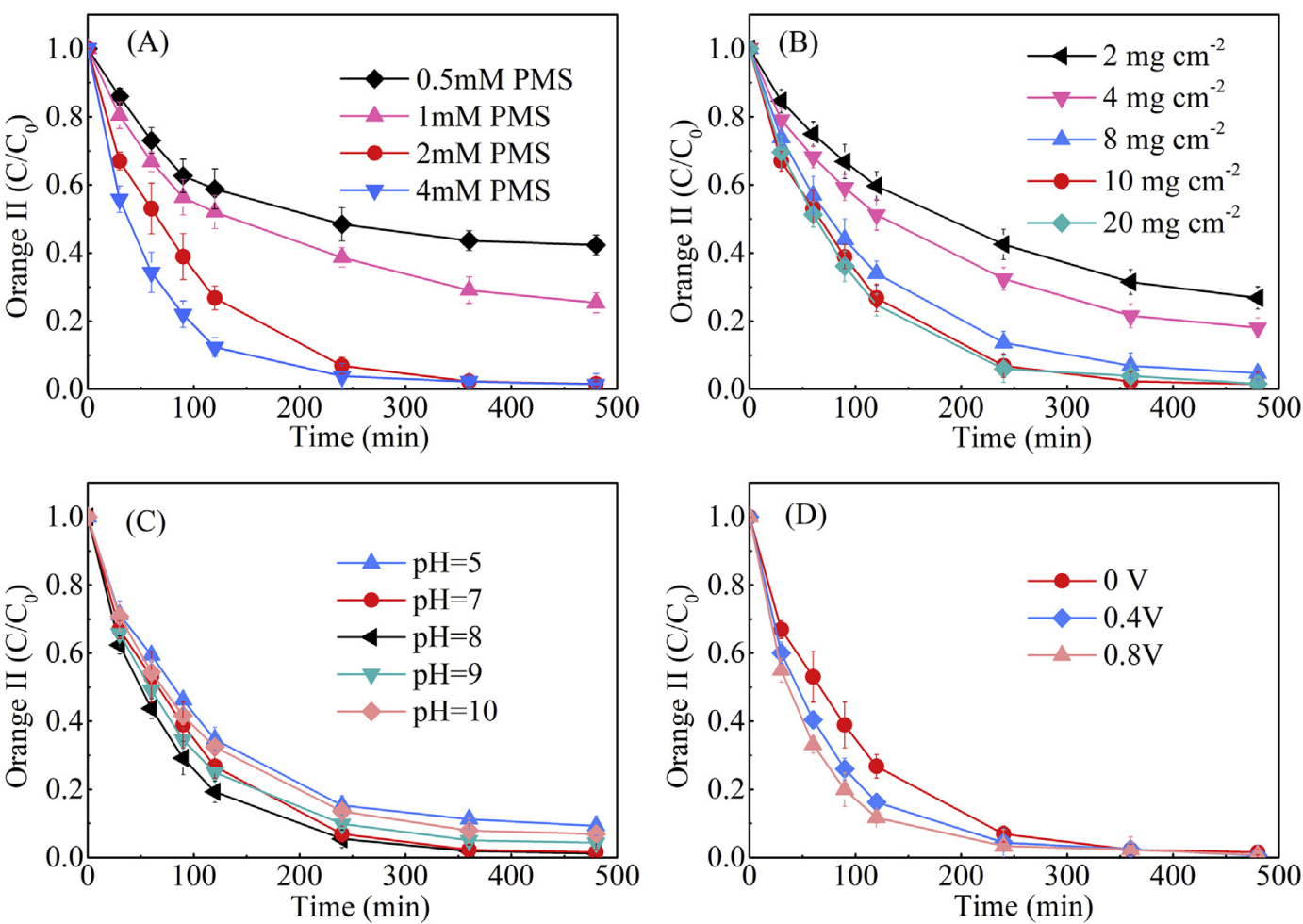

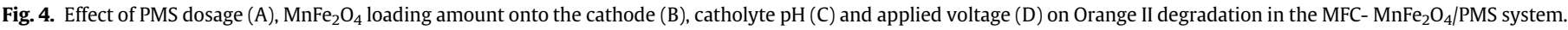
(For interpretation of the references to colour in this figure legend, the reader is referred to the Web version of this article.)

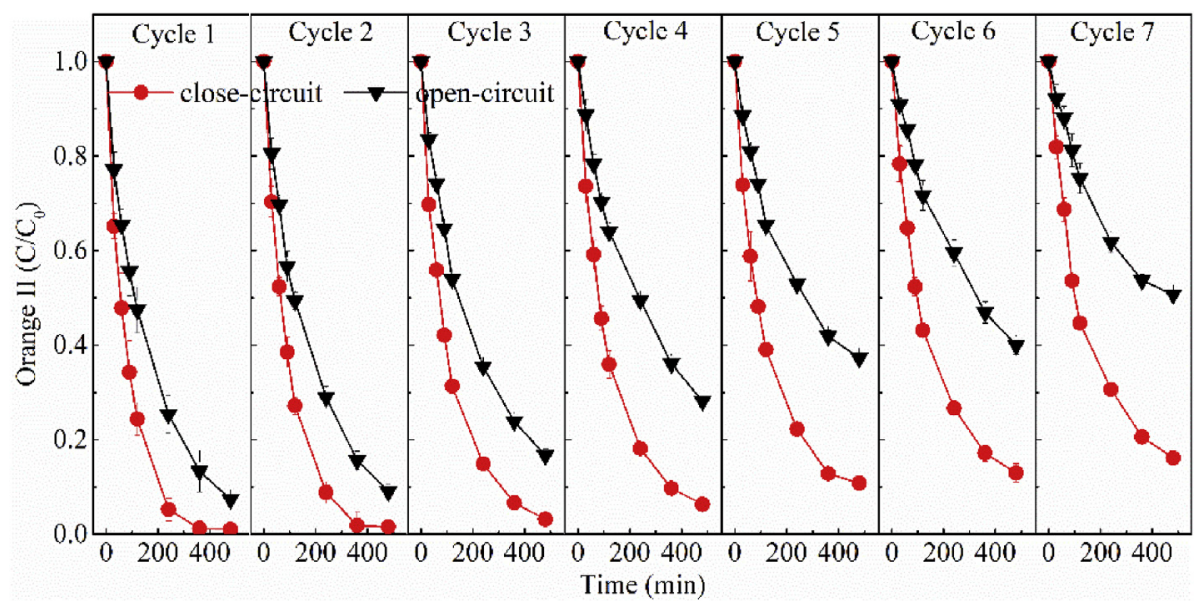

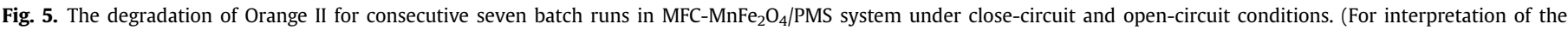
references to colour in this figure legend, the reader is referred to the Web version of this article.)

by Ren et al. (2015). They also found that the percentage of $\mathrm{M}^{2+}(\mathrm{M}$ : $\mathrm{Co}, \mathrm{Cu}, \mathrm{Mn}$ and $\mathrm{Zn}$ ) and $\mathrm{Fe}^{3+}$ in the $\mathrm{MFe}_{2} \mathrm{O}_{4}$ catalyst declined to a certain degree after PMS-based oxidation reaction.

However, according to the deconvolution of $\mathrm{Mn}(2 \mathrm{p}), \mathrm{Mn}^{2+}$ remained a higher fraction $(72.7 \%)$ for the electrode used in the MFC assisted $\mathrm{MnFe}_{2} \mathrm{O}_{4} / \mathrm{PMS}$ system comparing to that (35.7\%) in the $\mathrm{MnFe}_{2} \mathrm{O}_{4} / \mathrm{PMS}$ control (i.e. open circuit without MFC assistance). Similar results were also observed for $\mathrm{Fe}^{2+}$, the $\mathrm{MnFe}_{2} \mathrm{O}_{4}$ cathode used under closed-circuit conditions remained a higher fraction of $\mathrm{Fe}^{2+}$ (37.1\%) than the one used under open-circuit conditions (17.5\%). These data also suggest $\mathrm{Mn}^{2+}$ rather than $\mathrm{Fe}^{2+}$ played a primary role in PMS acitvation.

On the basis of the above results, a possible mechanism for
Orange II degradation in the MFC- $\mathrm{MnFe}_{2} \mathrm{O}_{4} / \mathrm{PMS}$ system was proposed, as shown in Fig. 7. Electroactive microbes attached on the anode of MFC may metabolize organic compounds and generate electrons and protons (Eq. (2)), and the electrons may be transferred via external circuit to the cathode. A variety of chemical or electrochemical reactions happen in the cathode chamber. PMS may be activated by $\equiv \mathrm{Mn}^{2+}$ and $\equiv \mathrm{Fe}^{2+}$ in the $\mathrm{MnFe}_{2} \mathrm{O}_{4}$ catalyst and decomposed to $\mathrm{SO}_{4}^{-}$, along with the production of $\equiv \mathrm{Mn}^{3+}$ and $\equiv \mathrm{Fe}^{3+}$ (Eq. (3) and (4)). $\equiv \mathrm{Mn}^{3+}$ and $\equiv \mathrm{Fe}^{3+}$ can be then reduced after accepting electrons from the cathode to achieve the redox cycle (Eqs. (5) and (6)), which promote the catalytic action of the $\mathrm{MnFe}_{2} \mathrm{O}_{4}$ cathode work successively. Although it has been reported that PMS can also be activated by electrons directly and generate 

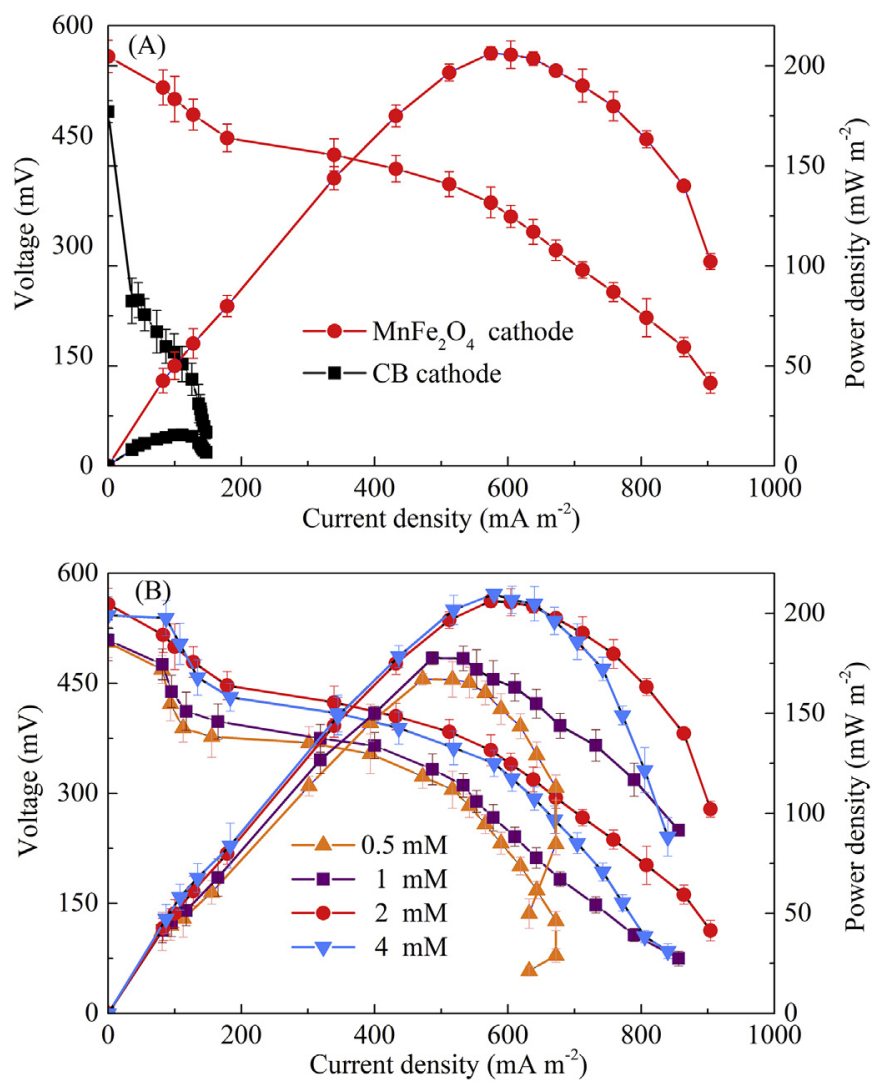

Fig. 6. Power density and polarization curves of the MFCs using $\mathrm{MnFe}_{2} \mathrm{O}_{4}$ cathode and $\mathrm{CB}$ cathodes, respectively (A), and of the MFCs using $\mathrm{MnFe}_{2} \mathrm{O}_{4}$ cathode under different PMS dosages (B). Error bars represent standard deviations of triplicate experiments.

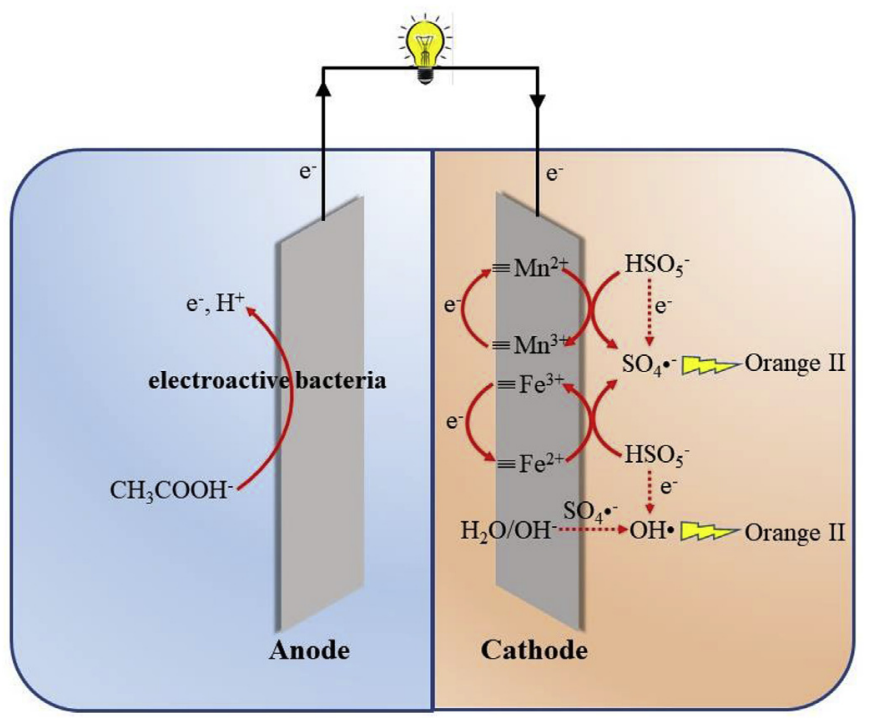

Fig. 7. Proposed mechanism for Orange II degradation in the MFC- $\mathrm{MnFe}_{2} \mathrm{O}_{4} / \mathrm{PMS}$ system. (For interpretation of the references to colour in this figure legend, the reader is referred to the Web version of this article.)

$\mathrm{SO}_{4}^{--}$on the cathode (Eq. (7)) (Yan et al., 2017), it is not the primary mechanism for PMS activation as seen from the results presented in Fig. 3A. In addition, $\mathrm{OH}^{*}$ can also be generated through direct activation of PMS by electrons and the reaction of $\mathrm{SO}_{4}^{--}$with $\mathrm{H}_{2} \mathrm{O} / \mathrm{OH}^{-}$ (Eqs. (8)-(10)) (Yan et al., 2017; Lin et al., 2018). The generated $\mathrm{SO}_{4}^{--}$ and $\mathrm{OH}^{*}$ have strong oxidative capabilities and will react with Orange II and cause it breakdown. To discriminate the role of $\mathrm{OH}^{*}$ in organic compounds transformation, we also conducted a separated experiment to quench $\mathrm{OH}^{\circ}$ in the $\mathrm{MFC}-\mathrm{MnFe}_{2} \mathrm{O}_{4} / \mathrm{PMS}$ system by adding tertbutyl alcohol (TAB), which can effectively scavenge $\mathrm{OH}^{\circ}$ but had no effect on $\mathrm{SO}_{4}^{-}$(Xie et al., 2018), and found the degradation of Orange II was inhibited slightly (Fig. S3). Therefore, we can infer that $\mathrm{SO}_{4}^{--}$based oxidation is the primary mechanism for Orange II degradation in the MFC- $\mathrm{MnFe}_{2} \mathrm{O}_{4} / \mathrm{PMS}$ system.

$$
\begin{aligned}
& \mathrm{CH}_{3} \mathrm{COO}^{-}+4 \mathrm{H}_{2} \mathrm{O} \rightarrow 2 \mathrm{HCO}_{3}^{-}+9 \mathrm{H}^{+}+8 \mathrm{e}^{-} \\
& \equiv \mathrm{Mn}^{2+}+\mathrm{HSO}_{5}^{-} \rightarrow \equiv \mathrm{Mn}^{3+}+\mathrm{SO}_{4}{ }^{--}+\mathrm{OH}^{-} \\
& \equiv \mathrm{Fe}^{2+}+\mathrm{HSO}_{5}^{-} \rightarrow \equiv \mathrm{Fe}^{3+}+\mathrm{SO}_{4}{ }^{--}+\mathrm{OH}^{-} \\
& \equiv \mathrm{Mn}^{3+}+\mathrm{e}^{-} \rightarrow \equiv \mathrm{Mn}^{2+} \\
& \equiv \mathrm{Fe}^{3+}+\mathrm{e}^{-} \rightarrow \equiv \mathrm{Fe}^{2+} \\
& \mathrm{HSO}_{5}^{-}+\mathrm{e}^{-} \rightarrow \mathrm{SO}_{4}{ }^{--}+\mathrm{OH} \\
& \mathrm{HSO}_{5}{ }^{-}+\mathrm{e}^{-} \rightarrow \mathrm{SO}_{4}{ }^{2-}+\mathrm{OH} \bullet \\
& \mathrm{SO}_{4}{ }^{--}+\mathrm{H}_{2} \mathrm{O} \rightarrow \mathrm{SO}_{4}{ }^{2-}+\mathrm{OH} \bullet+\mathrm{H}^{+} \\
& \mathrm{SO}_{4}{ }^{--}+\mathrm{OH}^{-} \rightarrow \mathrm{SO}_{4}{ }^{2-}+\mathrm{OH} \bullet
\end{aligned}
$$

The regeneration ability of $\equiv \mathrm{Mn}^{2+}$ and $\equiv \mathrm{Fe}^{2+}$ greatly decides the longevity of the $\mathrm{MnFe}_{2} \mathrm{O}_{4}$ catalyst. Although $\equiv \mathrm{Mn}^{2+}$ and $\equiv \mathrm{Fe}^{2+}$ regeneration may be achieved through chemical reduction by $\mathrm{HSO}_{5}$, such reaction is not always efficient because the reduction potential of $\mathrm{HSO}_{5}^{-}(1.82 \mathrm{~V})$ is higher than $\mathrm{Mn}^{3+} / \mathrm{Mn}^{2+}(1.54 \mathrm{~V})$ and $\mathrm{Fe}^{3+} / \mathrm{Fe}^{2+}(0.77 \mathrm{~V})$, which makes these reduction reactions thermodynamically unfavorable (Anipsitakis and Dionysiou, 2004; Zhang et al., 2013; Yao et al., 2014a; Xiao et al., 2018b). In this study, MFC driven as an extra electrons source promotes $\equiv \mathrm{Mn}^{2+}$ and $\equiv \mathrm{Fe}^{2+}$ regeneration through electrochemical reduction of $\equiv \mathrm{Mn}^{3+}$ and $\equiv \mathrm{Fe}^{3+}$ on the cathode, which may contribute greatly to the enhanced organic degradation rate, recyclability and longevity of the catalyst.

\section{Conclusion}

In this study, a novel wastewater treatment process (MFC$\mathrm{MnFe}_{2} \mathrm{O}_{4} / \mathrm{PMS}$ ) was developed through integrating MFC with $\mathrm{MnFe}_{2} \mathrm{O}_{4} / \mathrm{PMS}$ based AOPs technology and investigated for Orange II degradation. MFC driven enhanced Orange II degradation in the $\mathrm{MnFe}_{2} \mathrm{O}_{4} / \mathrm{PMS}$ system, with the degradation rate constant increased to 1.8 times of the control. Nearly a complete removal of Orange II $\left(100 \mathrm{mg} \mathrm{L}^{-1}\right)$ was attained in the MFC- $\mathrm{MnFe}_{2} \mathrm{O}_{4} / \mathrm{PMS}$ under the optimum conditions of $2 \mathrm{mM}$ PMS, $10 \mathrm{mg} \mathrm{cm}^{-2} \mathrm{MnFe}_{2} \mathrm{O}_{4}$ loading, $\mathrm{pH} 7-8$ and $480 \mathrm{~min}$ reaction time. MFC driven also extended the longevity of the $\mathrm{MnFe}_{2} \mathrm{O}_{4}$ catalyst possibly due to the in-situ regeneration of $\equiv \mathrm{Mn}^{2+}$ and $\equiv \mathrm{Fe}^{2+}$ via accepting electrons delivered to the cathode, and over $80 \%$ of Orange II was still removed in the $7^{\text {th }}$ run. Additionally, the MFC- $\mathrm{MnFe}_{2} \mathrm{O}_{4} / \mathrm{PMS}$ system could also recover electricity during Orange II degradation with a maximum power density of $206.2 \pm 3.1 \mathrm{~mW} \mathrm{~m}^{-2}$. Advanced oxidative process based on $\mathrm{SO}_{4}^{-}$from PMS activation by the $\mathrm{MnFe}_{2} \mathrm{O}_{4}$ catalyst was the primary mechanism for Orange II degradation in the systems. This MFC-MnFe $\mathrm{O}_{4} / \mathrm{PMS}$ technology, in 
nature of advanced oxidation mechanism, may also be used for the degradation of other organic compounds besides azo dyes in this work.

\section{Acknowledgements}

This work was supported by "Natural Science Foundation of China" (No. 51678055).

\section{Appendix A. Supplementary data}

Supplementary data to this article can be found online at https://doi.org/10.1016/j.chemosphere.2018.11.077.

\section{References}

Aguilar, Z.G., Brillas, E., Salazar, M., Nava, J.L., Sirés, I., 2017. Evidence of Fenton-like reaction with active chlorine during the electrocatalytic oxidation of Acid Yellow 36 azo dye with Ir-Sn-Sb oxide anode in the presence of iron ion. Appl. Catal. B Environ. 206, 44-52.

Allen, J.B., Larry, R.F., 2001. Electrochemical Methods: Fundamentals and Applications. Department of Chemistry and Biochemistry University of Texas at Austin, John Wiley \& Sons, Inc, pp. 156-176.

Anipsitakis, G.P., Dionysiou, D.D., 2004. Radical generation by the interaction of transition metals with vommon oxidants. Environ. Sci. Technol. 38, 3705-3712.

Cai, C., Zhang, H., Zhong, X. Hou, L., 2015. Ultrasound enhanced heterogeneous activation of peroxymonosulfate by a bimetallic Fe-Co/SBA-15 catalyst for the degradation of Orange II in water. J. Hazard Mater. 283, 70-79.

Chen, X., Qiao, X., Wang, D., Lin, J., Chen, J., 2007. Kinetics of oxidative decolorization and mineralization of Acid Orange 7 by dark and photoassisted $\mathrm{Co}^{2+}$-catalyzed peroxymonosulfate system. Chemosphere 67, 802-808.

Chen, H., Motuzas, J., Martens, W., Diniz da Costa, J.C., 2018. Degradation of azo dye Orange II under dark ambient conditions by calcium strontium copper perovskite. Appl. Catal. B Environ. 221, 691-700.

Dai, R., Chen, X., Xiang, X., Wang, Y., Wang, F., 2018. Understanding azo dye anaerobic bio-decolorization with artificial redox mediator supplement: considering the methane production. Bioresour. Technol. 249, 799-808.

Feng, C.H., Li, F.B., Mai, H.J., Li, X.Z., 2010. Bio-electro-Fenton process driven by microbial fuel cell for wastewater treatment. Environ. Sci. Technol. 44, 1875-1880.

Ghanbari, F., Moradi, M., 2017. Application of peroxymonosulfate and its activation methods for degradation of environmental organic pollutants: Review. Chem Eng. J. 102, 307-315.

Guan, Y.H., Ma, J., Ren, Y.M., Liu, Y.L., Xiao, J.Y., Lin, L.O, Zhang, C., 2013. Efficient degradation of atrazine by magnetic porous copper ferrite catalyzed peroxymonosulfate oxidation via the formation of hydroxyl and sulfate radicals. Water Res. 47, 5431-5438.

Higuchi, E., Uchida, H., Watanabe, M., 2005. Effect of loading level in platinumdispersed carbon black electrocatalysts on oxygen reduction activity evaluated by rotating disk electrode. J. Electroanal. Chem. 583, 69-76.

Hou, J., Yang, S., Wan, H., Fu, H., Qu, X., Xu, Z., Zheng, S., 2018. Highly effective catalytic peroxymonosulfate activation on $\mathrm{N}$-doped mesoporous carbon for $\mathrm{O}$ phenylphenol degradation. Chemosphere 197, 485-493.

Huang, L., Wang, O, Jiang, L., Zhou, P., Quan, X., Logan, B.E., 2015. Adaptively evolving bacterial communities for complete and selective reduction of $\mathrm{Cr}(\mathrm{VI})$, $\mathrm{Cu}(\mathrm{II})$, and $\mathrm{Cd}(\mathrm{II})$ in biocathode bioelectrochemical systems. Environ. Sci. Technol. 49, 9914-9924.

Huang, G.X., Wang, C.Y. Yang, C.W., Guo, P.C., Yu, H.Q. 2017. Degradation of bisphenol A by peroxymonosulfate catalytically activated with $\mathrm{Mn}_{1.8} \mathrm{Fe}_{1.2} \mathrm{O}_{4}$ nanospheres: synergism between $\mathrm{Mn}$ and Fe. Environ. Sci. Technol. 51, $12611-12618$.

Jaafarzadeh, N., Ghanbari, F., Ahmadi, M., 2017. Efficient degradation of 2,4 dichlorophenoxyacetic acid by peroxymonosulfate/magnetic copper ferrite nanoparticles/ozone: a novel combination of advanced oxidation processes. Chem. Eng. J. 320, 436-447.

Lefebvre, O., Neculita, C.M., Yue, X., Ng, H.Y., 2012. Bioelectrochemical treatment of acid mine drainage dominated with iron. J. Hazard Mater. 241-242, 411-417.

Li, C.X., Chen, C.B., Lu, J.Y., Cui, S., Li, J., Liu, H.Q. Li, W.W., Zhang, F., 2018. Metal organic framework-derived $\mathrm{CoMn}_{2} \mathrm{O}_{4}$ catalyst for heterogeneous activation of peroxymonosulfate and sulfanilamide degradation. Chem. Eng. J. 337, 101-109.

Liang, S., Zhang, B.G., Shi, J.X., Wang, T., Zhang, L.F., Wang, Z.J., Chen, C.B., 2018 mproved decolorization of dye wastewater in an electrochemical system powered by microbial fuel cells and intensified by micro-electrolysis.
Bioelectrochemistry 124, 112-118.

Lin, K.A., Yang, M.T. Lin, J.T., Du, Y., 2018. Cobalt ferrite nanoparticles supported on electrospun carbon fiber as a magnetic heterogeneous catalyst for activating peroxymonosulfate. Chemosphere 208, 502-511.

Pan, Y., Wang, Y., Zhou, A., Wang, A., Wu, Z., Lv, L., Li, X., Zhang, K., Zhu, T., 2017. Removal of azo dye in an up-flow membrane-less bioelectrochemical system integrated with bio-contact oxidation reactor. Chem. Eng. J. 326, 454-461.

Peng, X., Yu, H., Wang, X., Zhou, Q., Zhang, S., Geng, L., Sun, J., Cai, Z., 2012. Enhanced performance and capacitance behavior of anode by rolling $\mathrm{Fe}_{3} \mathrm{O}_{4}$ into activated carbon in microbial fuel cells. Bioresour. Technol. 121, 450-453.

Qi, C., Liu, X., Ma, J., Lin, C., Li, X., Zhang, H., 2016. Activation of peroxymonosulfate by base: implications for the degradation of organic pollutants. Chemosphere 151, 280-288.

Rani, S.K., Easwaramoorthy, D., Bilal, I.M., Palanichamy, M., 2009. Studies on Mn(II)catalyzed oxidation of $\alpha$-amino acids by peroxomonosulphate in alkaline medium-deamination and decarboxylation: a kinetic approach. Appl. Catal. Gen. 369, 1-7.

Ren, Y., Lin, L., Ma, J., Yang, J., Feng, J., Fan, Z., 2015. Sulfate radicals induced from peroxymonosulfate by magnetic ferrospinel $\mathrm{MFe}_{2} \mathrm{O}_{4}(\mathrm{M}=\mathrm{Co}, \mathrm{Cu}, \mathrm{Mn}$, and $\mathrm{Zn})$ as heterogeneous catalysts in the water. Appl. Catal. B Environ. 165, 572-578.

Sangeun, Oh, Booki Min, A., Logan, B.E., 2004. Cathode performance as a factor in electricity generation in microbial fuel cells. Environ. Sci. Technol. 38, 4900-4904.

Shao, H., Zhao, X., Wang, Y., Mao, R., Wang, Y., Qiao, M., Zhao, S., Zhu, Y., 2017. Synergetic activation of peroxymonosulfate by $\mathrm{Co}_{3} \mathrm{O}_{4}$ modified $\mathrm{g}-\mathrm{C}_{3} \mathrm{~N}_{4}$ for enhanced degradation of diclofenac sodium under visible light irradiation. Appl. Catal. B Environ. 218, 810-818.

Wang, Y.R., Chu, W., 2011. Degradation of a xanthene dye by Fe(II)-mediated activation of Oxone process. J. Hazard Mater. 186, 1455-1461.

Wu, S., Li, H., Zhou, X., Liang, P., Zhang, X., Jiang, Y., Huang, X., 2016. A novel pilotscale stacked microbial fuel cell for efficient electricity generation and wastewater treatment. Water Res. 98, 396-403.

Xia, D., Li, Y., Huang, G., Yin, R., An, T., Li, G., Zhao, H., Lu, A., Wong, P.K., 2017. Activation of persulfates by natural magnetic pyrrhotite for water disinfection: efficiency, mechanisms, and stability. Water Res. 112, 236-247.

Xiao, R., Luo, Z., Wei, Z., Luo, S., Spinney, R., Yang, W., Dionysiou, D.D., 2018a. Activation of peroxymonosulfate/persulfate by nanomaterials for sulfate radical-based advanced oxidation technologies. Curr. Opin. Chem. Eng. 19, $51-58$.

Xiao, L., Liu, F., Liu, J., Li, J., Zhang, Y., Yu, J., Wang, O., 2018b. Nano-Fe $\mathrm{O}_{4}$ particles accelerating electromethanogenesis on an hour-long timescale in wetland soil. Environ. Sci.: Nano 5, 436-445.

Xie, R., Ji, J., Huang, H., Lei, D., Fang, R., Shu, Y., Zhan, Y., Guo, K., Leung, D.Y.C., 2018. Heterogeneous activation of peroxymonosulfate over monodispersed $\mathrm{Co}_{3} \mathrm{O}_{4} /$ activated carbon for efficient degradation of gaseous toluene. Chem. Eng. J. 341, 383-391.

Xu, H., Quan, X., Xiao, Z., Chen, L., 2018. Effect of anodes decoration with metal and metal oxides nanoparticles on pharmaceutically active compounds removal and power generation in microbial fuel cells. Chem. Eng. J. 335, 539-547.

Yan, S., Geng, J., Guo, R., Du, Y., Zhang, H., 2017. Hydronium jarosite activation of peroxymonosulfate for the oxidation of organic contaminant in an electrochemical Reactor driven by microbial fuel cell. J. Hazard Mater. 333, 358.

Yao, Y., Cai, Y., Lu, F., Wei, F., Wang, X., Wang, S., 2014a. Magnetic recoverable $\mathrm{MnFe}_{2} \mathrm{O}_{4}$ and $\mathrm{MnFe}_{2} \mathrm{O}_{4}$-graphene hybrid as heterogeneous catalysts of peroxymonosulfate activation for efficient degradation of aqueous organic pollutants. J. Hazard Mater. 270, 61-70.

Yao, Y., Cai, Y., Lu, F., Qin, J., Wei, F., Xu, C., Wang, S., 2014b. Magnetic $\mathrm{ZnFe}_{2} \mathrm{O}_{4}-\mathrm{C}_{3} \mathrm{~N}_{4}$ hybrid for photocatalytic degradation of aqueous organic pollutants by visible light. Ind. Eng. Chem. Res. 53, 17294-17302.

Zhang, B., Feng, C., Ni, J., Zhang, J., Huang, W., 2012. Simultaneous reduction of vanadium(V) and chromium(VI) with enhanced energy recovery based on microbial fuel cell technology. J. Power Sources 204, 34-39.

Zhang, T., Zhu, H., Croué, J.P., 2013. Production of sulfate radical from peroxymonosulfate induced by a magnetically separable $\mathrm{CuFe}_{2} \mathrm{O}_{4}$ spinel in water: efficiency, stability, and mechanism. Environ. Sci. Technol. 47, 2784-2791.

Zhang, B.G., Wang, Z.J., Zhou, X., Shi, C.H., Guo, H.M., Feng, C.P., 2015. Electrochemical decolorization of methyl orange powered by bioelectricity from single-chamber microbial fuel cells. Bioresour. Technol. 181, 360-362.

Zhao, Z. Zhao, J. Yang, C. 2017. Efficient removal of ciprofloxacin by peroxymonosulfate $/ \mathrm{Mn}_{3} \mathrm{O}_{4}-\mathrm{MnO}_{2}$ catalytic oxidation system. Chem. Eng. J. 327, $481-489$.

Zhao, X., Niu, C., Zhang, L., Guo, H., Wen, X., Liang, C., Zeng, G., 2018. Co-Mn layered double hydroxide as an effective heterogeneous catalyst for degradation of organic dyes by activation of peroxymonosulfate. Chemosphere 204, 11-22.

Zhou, R., Zhao, J., Shen, N., Ma, T., Su, Y., Ren, H., 2018. Efficient degradation of 2,4dichlorophenol in aqueous solution by peroxymonosulfate activated with magnetic spinel $\mathrm{FeCO}_{2} \mathrm{O}_{4}$ nanoparticles. Chemosphere 197, 670-679. 